\title{
Plant Extract of Ruta Graveolens Standardized in Furanocoumarins: Resistance Elicitorin Rice Plants against Magnaporthe Oryzae
}

\section{Rejanne Lima Arruda ${ }^{1}$, Mariana Cristina de Morais Rodrigues ${ }^{1}$, Márcio Vinicius de Carvalho Barros Côrtes' ${ }^{2}$, Marta Cristina Corsi de Filippi², Gabriel Moura Mascarin², Edemilson Cardoso da Conceição ${ }^{1}$}

${ }^{1}$ Federal University of Goiás, Faculty of Pharmacy, Research Laboratory of Natural Products, Goiânia, GO, Brazil.

${ }^{2}$ Embrapa Rice and Beans, Santo Antônio de Goiás, GO, Brazil.

\begin{abstract}
We explored furanocoumarin compounds extracted from herb Ruta graveolens to suppress the blast rice disease by eliciting rice systemic resistance pathways. The plant material was subjected to the extraction method by percolation with $80 \%$ hydroethanolic solution, which allowed the obtaining of the furanocoumarins, that were monitored by HPLC.Tests were carried out in vitro and in greenhouse. The experimental design was entirely randomized with 24 treatments and 3 replicates. The concentration of $6.75 \mathrm{mg} / \mathrm{mL}$ of extract providedthe highest chitinase activity in the period of 24 and 48 hours before inoculation with the pathogen, with the latter referring to 2.67 and $2.70 \mathrm{mg}$ of glic. $\mathrm{h}^{-1} . \mathrm{mg} \mathrm{prot}^{-1}$, respectively, for chitinase and 6.04 and $7.84 \mathrm{mg}$ of gly.h ${ }^{1} . \mathrm{mg}$ prot $^{-1}$, respectively for $\beta$-1,3-glucanase.The concentrations of $0.7 \mathrm{mg} / \mathrm{mL}$ psoralen and $1.2 \mathrm{mg} / \mathrm{mL}$ bergapten strongly induced the defense mechanisms of rice plants translating in substantial reduction of disease severity in more than $90 \%$. These results underscore the potential application of a plant extract containing furanocoumarins to mitigate the bursting burden of rice by increasing the mechanisms of systemic resistance. The use of plant extracts allows the reduction of the disease through several different mechanisms, which makes this strategy very efficient and innovative.
\end{abstract}

Keywords: Rue, Blast, Induction of resistance, PRPs

\section{INTRODUCTION}

The occurrence of diseases in agricultural crops is a global problem that brings manyeconomic and socialdamages to the small and large producer. Production costs highdue to the many chemical fungicides pulverization to minimize damages to the plants and crop losses caused by fungal phytopathogens [1].

Among the main cereal crops in Brazil, rice is one of the sources of food for Brazilians. The production of this cereal in Brazil in 2015 was 473.8 million tons [2]. Among the biotic factors that cause relevant losses in this crop, blastis the most destructive and seriousdisease, and can lead to losses of up to $100 \%$ in grain yield, causing millionaire losses [3]. The expenseson fungicides for rice blast control isabout $30 \%$ of the total production cost, and the main fungicides utilized belong to the groups of triazoles, strobilurins and benzothiazoles [3].

The integration of genetic resistance, cultural practes, chemical and alternativecontrolis adopted and comprise valuable tools for the sustainable management rice blast.The search for natural fungicides, mainly based on plant extracts and plant defenseelicitors [4] are considerated innovative and promising methodsthe. Incorporation of vegetal extracts into integrated management programs aims to reduce the negative impacts caused by conventional chemical treatments [5]. However, the successful adoption of plant extracts depends of its quality, safety and efficacy. Thus, the standardization of plant extracts is an important method to guarantee these requirements and by the consumer market [6] and for a successfully plant diseasescontrol.

Studies on plant disease control mechanisms by plant extracts reveal that itmay have direct activity in the pathogen or in inducing defense responses in the host plant, resulting in reduced disease 
development [7].Resistance induction involves the activation of several mechanisms that include the increase of Pathogen-Related Proteins (PRPs) such as chitinase (CHI), $\beta-1,3$ glucanase (GLU), peroxidase (POX), lipoxygenase (LOX) and phenylalanine ammonia (PAL), and defense hormones such as salicylic acid, which may act alone or together with other markers such as jasmonic acid and ethylene [8]in different pathways.

Ruta graveolens L. (Rutaceae), also popularly known as "rue", has as its secondary metabolites alinear furanocoumarins such as psoralen and bergapten. Both secondary metabolites, exhibitapotential role as antifungal activity, since these compoundspossessantimicrobial propertiesproduced by the secondary metabolism of plants when underthe attack of apathogen (these compounds are also known as phytoalexins) [9].

The mechanism by which plant extracts act to promote the suppression of plant diseases is the most important step to understand its role as natural fungicides and is being currently studied by several researchers [10].

In view of the great genetic variability within $M$. oryzaecoupled with problems caused by the over-use of fungicides in rice cultivation, The main goal in this work was to investigate the role of $R$.graveolensextract of standardized in furanocoumarins as a inducers of systemic defencein rice plants, with the purpose of mitigating the blast severity on rice plants.

\section{MATERIAL AND MeThOdS}

\subsection{Characterization of R.Graveolensplant}

The aerial part of R.graveolens was acquired from the company Paladar Condimentos Ltda., located in the city of Goiânia -GO, Brazil. The plant material had batch number: 7838987673213. The plant material was submitted to quality control analysis as: loss by desiccation, determination of the total ash content, determination of the acid insoluble ash content, determination of the granulometric distribution, determination of the Intumescence index and analysis by thin layer chromatography. All analyzes were performed according to the methodology of Brasil [11].

\subsection{R.graveolens Extract}

The aerial part of the plant was ground by using a knife mill and the hydroethanolic extract was obtained by the percolation method[11].Briefly, onekilogram of plant material in $10 \mathrm{~L}$ of $80 \%(\mathrm{v} / \mathrm{v})$ hydroethanolic solution was used.The extract was subjected to the rotevaporation process to remove the solvent until solids content of $20 \%$ was obtained. The solid phase was then dried at room temperature by means of mechanical ventilation until the solids content reached $90 \%$.

\subsubsection{Characterization of $R$. Graveolens Extract}

The concentrated vegetal extract obtained in item 2.2 was standardized and characterized by the identification and quantification of furanocoumarins (psoralen and bergapten were used as the biochemical markers), according to the method described by Martins [12].

\section{Photostability of R. Graveolens Extract}

The standardized plant extract in furanocoumarins obtained in item 2.3 was subjected to the accelerated photostability test using a chamber (Nova Ética, Brazil) equipped with a near UV fluorescence lamp (15 W) with a spectral distribution of 320-400 nm and several Cold white fluorescent lamps $(15 \mathrm{~W})$. The samples were exposed to radiation during the period of 4, 8, 24 and 48 hours and were subsequently analyzed by HPLC, model HPLC Alliance, with separation module e2695, equipped with a quaternary pump, diode arrangement detector (PDA) 2998 and data processing system software Enpower 3 for quantification of furanocoumarins under this study. The methodology used to reported method [13,14].

\subsection{Fractionation of R.Graveolens Extract and Quantification of Furanocoumarins in their Fractions}

The standardized plant extract was submitted to fractionation by liquid-liquid partitioning using 83 $\mathrm{mL}$ (3 times) of solvents with different polarities: hexane, ethyl acetate and n-butanol to obtain FHex (Hexane fraction), FAc (Ethyl acetate fraction), and FBut (Butyl fraction), aiming at the separation of the substances present in the extract through their polarities. The fraction remaining after extraction 
with the solvents was denominated hydromethanic fraction (FHD). The fractions obtained were concentrated through the use of a rotary evaporator and subjected to the identification and quantification of furanocoumarins (psoralen and bergapten) by HPLC analysis, using the method described by Martins [12].

\subsection{Evaluation of the R.Graveolens Extract Activity of, its Fractions and the Biological Markers Furanocoumarins in the Suppression of Brusone in Greenhouse}

\subsubsection{Planting}

Seeds of the up land rice (Oryza sativa L.) cultivar 'Primavera' were surface sterilized with sodium hypochlorite $(1 \mathrm{~min}), 70 \%$ ethanol $(1 \mathrm{~min})$ and distilled water.Surface-sterilized rice seeds were then sown in $84-\mathrm{cm}$-long grooves in a plastic tray containing approximately $3 \mathrm{~kg}$ of soil fertilized with $5 \mathrm{~g}$ of NPK, $1 \mathrm{~g}$ of zinc sulfate and $3 \mathrm{~g}$ of ammonium sulfate. Acover fertilization with $2 \mathrm{~g}$ of ammonium sulfate per tray was performed at 20 days after sowing [15].

\subsubsection{Obtaining the Conidial Suspension of M. Oryzae}

The conidial suspension of $M$. oryzae, isolate BRM 31.295 was obtained according to the methodology described by [16,17], with final concentration adjusted for $3 \times 10^{5}$ conidia. $\mathrm{mL}^{-1}$. M.oryzae isolate is designated BRM 31.295 from the collection of microorganisms and functional fungi of EMBRAPA rice and beans.

\subsubsection{Blast Suppression Evaluation of Rice Leaves by Induction Test}

\section{Treatments and Spray Inoculation}

The experimental design was completely randomized, with 21 treatments and 3 replicates (Table 1). The standard psoralen was not used alone, since preliminary tests in the same reaction caused phytotoxicity on the plant.Fyfteen $\mathrm{mL}$ of each treatment was sprayed over the 21 days old rice plants, at 48 hours before the spray inoculation with $15 \mathrm{mLM}$. oryzae conidial suspention $\left(3.10^{5}\right.$ conidia $\mathrm{mL}$ ${ }^{1}$ ). The positive control consisted in the use of $15 \mathrm{~mL}$ of the conidial suspension, and negative control was used only water.

Table1. Concentration of treatments used in the blast suppression test in greenhouse

\begin{tabular}{|c|c|c|c|}
\hline \multirow{2}{*}{ Concentration } & Extract of R. graveolens and their & \multicolumn{2}{|c|}{ Standards } \\
\cline { 3 - 4 } & fractions (FHex, FAc, FBut, & Psoralen & Bergapten \\
\hline $\mathrm{C} 1$ & $4 \mathrm{mg} \mathrm{mL}^{-1}$ & $18.70 \mu \mathrm{g} \mathrm{mL}^{-1}$ & $32.65 \mu \mathrm{g} \mathrm{mL}^{-1}$ \\
\hline $\mathrm{C} 2$ & $5,4 \mathrm{mg} \mathrm{mL}^{-1}$ & $34.07 \mu \mathrm{gL} \mathrm{m}^{-1}$ & $59.51 \mu \mathrm{gL}^{-1}$ \\
\hline $\mathrm{C} 3$ & $6,75 \mathrm{mg} \mathrm{mL}^{-1}$ & $53.25 \mu \mathrm{gL}^{-1}$ & $92.94 \mathrm{~g} \mathrm{~mL}^{-1}$ \\
\hline
\end{tabular}

*Fractions: FHex: hexane fraction; FAc: fraction of ethyl acetate; But: Butyl fraction, FHD: hydrometanic fraction; Pso: Psoralen; Bg: Bergapten.

\section{Evaluation}

Leaf blast severity evaluation, were done seven days after pathogen spray inoculation, using evaluation scales [18]. The images related to the lesion type in the leaves were obtained by the digital camera Leica ${ }^{\circledR}$ EC 3 coupled to the Leica ${ }^{\circledR}$ S6 D magnifying glass.

\subsection{Quantification of Enzymes Activity and Salicylic Acid Levels}

\subsubsection{Samppling and Protein Extraction}

Rice leaves were collected in the period of 24 and 48 hours before and afterinoculation of the plantwithM. oryzae. The samples were frozen in liquid nitrogen and macerated in a mortar with pestle,until obtaining a fine powder. The powder was added in microtubes and kept in an ice bath. An extraction buffer was used to obtain the protein extract, consisting of $10 \mathrm{mM}$ Tris- $\mathrm{HCl}, 150 \mathrm{mM}$ $\mathrm{NaCl}, 2 \mathrm{mM}$ EDTA, $2 \mathrm{mM}$ DTT (Dithiotreitol), $1 \mathrm{mM}$ PMSF (fluoromethyl phenylmethanesulfonyl), $10 \mathrm{mgmL}^{-1}$ leptin and apotinine $10 \mathrm{mgmL}^{-1}$ in the ratio $1: 4(\mathrm{v} / \mathrm{v})$. The samples were shaken for one minute and then centrifuged at $10.000 \mathrm{rpm}$ at $4^{\circ} \mathrm{C}$ for $5 \mathrm{~min}$ to obtain the supernatant for the protein dosage and the enzymatic assays. 


\subsubsection{Quantification of Total Proteins}

The quantification of the total proteins was determined by the colorimetric to reported method [19], and the reading was performed in a Fento 600 plus spectrophotometer, with wavelength at $595 \mathrm{~nm}$ using the software Gen5 Data Analyzes (Biotek). A standard curve of protein content was prepared with bovine serum albumin (BSA) for the conversion of the readings from analyzed samples.

Chitinase Activity (CHI, EC 3.2.1.14)

It was determined, By adding $300 \mu \mathrm{L}$ of $1 \%$ (v/v) colloidal chitin in $1.0 \mathrm{M}$ sodium acetate buffer and pH 5.0 and $50 \mu \mathrm{L}$ of protein extracts from each sample in triplicate,, as describedby the Kuc [20].

Activity of $\beta 1,3$ Glucanase (GLU, EC 3.2.1.6)

The method described by Kuc and Côrtes [20,21], using $50 \mu \mathrm{L}$ of the extracts from each sample in triplicate, adding $300 \mu \mathrm{L}$ of $1 \%$ laminarin in $1.0 \mathrm{M}$ sodium acetate buffer and $\mathrm{pH}$ 5.0.

Lipoxygenase Activity (LOX, EC 1.13.11.12)

According to the method mentioned by Axelrod [22], using 1\% (v/v) linoleic acid as a substrate in 50 $\mathrm{mM}$ phosphate buffer and $\mathrm{pH} 6.0,100 \mu \mathrm{L}$ of the extract of each sample in triplicate was added.

Phenylalanine Ammonium Lyase Activity (PAL, EC 4.3.1.5)

The product generated (trans - cinnamic acid) were quantified by the hydrolysis of the Lphenylalanine substrate by the method described by Alunni[23], using $1.5 \mathrm{~mL}$ of $10 \mathrm{mM}$ phenylalanine solution in $100 \mathrm{mM}$ borate buffer and $\mathrm{pH}$ 9.0.

Peroxidase Activity (POX, EC 1.11.1.7)

It was determined by the methods described by Côrtes [21], using $1 \mathrm{~mL}$ of ABTS $0.4 \mathrm{mgmL}^{-1}$ solution in $0.1 \mathrm{M}$ sodium acetate buffer and $\mathrm{pH} 4$.

\subsubsection{Extraction and Quantification of Salicylic Acid Contents}

Samples were injected in PelkinHelmer, C18, $5 \mu \mathrm{m}$ x $250 \mathrm{~mm}$ x $2.1 \mathrm{~mm}$ HPLC column with mobile phase $23 \%$ methanol: $77 \% 20 \mathrm{mM}$ acetate buffer, $\mathrm{pH}$ 5.0, flow $0.2 \mathrm{~mL} \cdot \mathrm{min}^{-1}$ and with reading at $\lambda=$ $280 \mathrm{~nm}$ at $30 \pm 2^{\circ} \mathrm{C}$ with retention time equal to 5.9 / minute. Chromera software was used to obtain the data $[24,25]$.

\subsubsection{Quantification of Phenolic Compounds in Rice Leaves}

It was performed according to reported method [26]. The tests were carried out using $300 \mathrm{mg}$ of macerated rice leaves in liquid nitrogen, which were then solubilized in a methanol/water mixture (2: 1) and subjected to ultrasound for $30 \mathrm{~min}$ for the extraction of the phenolic compounds. After extraction, filtration was performed and $120 \mu \mathrm{L}$ of the filtrate was homogenized with $220 \mu \mathrm{L}$ of the Folin-Ciocalteu reagent and incubated for $5 \mathrm{~min}$. After incubation, $300 \mu \mathrm{L}$ of $\mathrm{Na}_{2} \mathrm{CO}_{3}$ (sodium carbonate) and $600 \mu \mathrm{L}$ of distilled water were added and the spectrophotometer read at $720 \mathrm{~nm}$.

\subsubsection{Statistical Analysis}

The results of leaf blast severity analysis and enzymatic quantification were evaluated by SPSS software version 18.0. The ANOVA test was performed and the treatments presented positive interaction. Subsequently the averages were compared by Tukey test $(\mathrm{P}<0.05)$. The results of enzymatic quantification were also subjected to a multivariate analysis of main components using the "FactoMiner" package[27] of the statistical software R (R Development Core Team, Vienna, Austria).Biplot type graphs were generated using the first two major components for datasets at 24 and 48 hours after fungal inoculation, separately. These graphs were intended to show the correlation between the main response variables of the trials and the treatments tested. In addition, a cluster analysis using Euclidean distances was performed with the variables of the main components 1 and 2, and the treatments, in order to generate a dendrogram using Ward's hierarchical method to group treatments with more than $90 \%$ similarity $(P>0.90)$ after 1000-replicate boostrap resampling [28] ("pvclust" package). 


\section{RESULTS}

\subsection{Plant Material Characterization}

The water loss by desiccation of the powder, indicative of the volatile material content of the plant and, indirectly, the residual moisture presented a value of $10.66 \%$, which is within the value established in the general methods section of the Brazilian Pharmacopoeia 5th edition [11], which indicates an efficient drying of the material.

\subsubsection{Total Ashes}

The total ash content found in the R.graveolens powder was $6.79 \%(\mathrm{~m} / \mathrm{m})$, which is within the value established by the general methods of the Brazilian Pharmacopoeia 5th edition [11], which is $2 \%$ $20 \%$, thus ensuring the quality of the plant material that was used.

\subsubsection{Acid Insoluble Ash}

The amount of acid-insoluble ash found in the sample was $0.26 \%(\mathrm{~m} / \mathrm{m})$, indicating that the plant sample had low contamination of soil and sand residues (siliceous materials).

\subsection{Fractionation of R. Graveolens Extract}

The methodology described in item 2.4 allowed the fractionation of the $R$. graveolens plant extract, and the highest yield was obtained with the hydromethanic fraction, which had a value of $10 \%$.

\subsection{Quantification of Furanocoumarins in R. Graveolens Extract and Respective Fractions}

The highest levels of psoralen and bergapten were found in the ethyl acetate fraction, being $1.59 \%$ and $2.47 \%$, respectively. Regarding the hydromethanic fraction, it was not possible to detect any of the analyzed patterns.

\subsection{Photoestability of Furanocoumarins}

There was no significant difference between the treatments submitted to the photoestability test in any of the analyzed periods, which indicates that the percentage of furanocoumarins under study is preserved when exposed to light for up to 48 hours.

\subsection{Suppression of Leaf Blast After Application of Greenhouse Treatments}

The best treatment $\left(6.75 \mathrm{mg} \mathrm{mL}^{-1}\right.$ of $R$. graveolensextract) presented the lowest leaf blast severity, with $1.3 \%$ of leave area with disease, representing $95.02 \%$ of reduction when compared to the positive control (Figure 1). The treatments with acetate, hexane and butanol fractions showed no significant difference in the concentration of $6.75 \mathrm{mg} \mathrm{mL}^{-1}$, with a reduction of disease greater than $90 \%$ (Table 2).

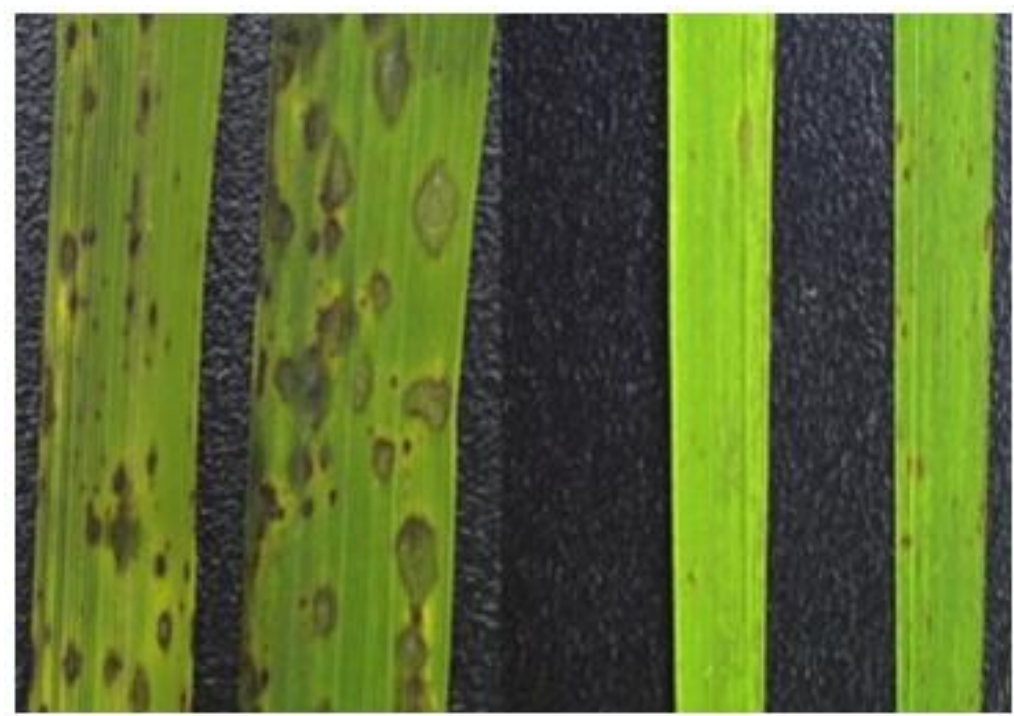

Figure1. Blast lesions on rice leaves. (A) positive control with rice leaves presenting high severity of the disease, (B) After treatment with R.graveolens $\left(6.75 \mathrm{mg} \mathrm{mL}^{-1}\right)$ in the induction test showing leaves with low severity (few lesions). 
Table2. Severity of leaf blast (\%) in rice plants after seven days of treatment with $R$. graveolens extract, its fractions and the standards in the induction test under greenhouse conditions

\begin{tabular}{|c|c|c|c|}
\hline \multirow[b]{2}{*}{ Treatments } & \multicolumn{3}{|c|}{ Concentrations $\left(\mathrm{mg} \mathrm{mL}^{-1} / \mu \mathrm{g} \mathrm{mL}^{-1}\right)$} \\
\hline & $\mathrm{C} 1$ & $\mathrm{C} 2$ & C3 \\
\hline Extract & $5.0 \mathrm{cdC}$ & $2.1 \mathrm{abB}$ & $1.3 \mathrm{aA}$ \\
\hline Bergapten & $3.2 \mathrm{abcB}$ & $2.4 \mathrm{aA}$ & $2.9 \mathrm{bcA}$ \\
\hline Psoralen+Bergapten & $3.1 \mathrm{abcB}$ & $2.8 \mathrm{abB}$ & $1.9 \mathrm{abA}$ \\
\hline Ethyl acetate fraction & 3.6 bcdB & $3.2 \mathrm{abcB}$ & $2.3 \mathrm{bA}$ \\
\hline Hexane fraction & 1.9 abcA & $2.4 \mathrm{aB}$ & $2.4 \mathrm{bB}$ \\
\hline Butyl fraction & 2.9 abcA & $6.5 \mathrm{~dB}$ & $2.0 \mathrm{bA}$ \\
\hline Hydrometanolic fraction & $3.1 \mathrm{abcA}$ & $3.1 \mathrm{abcA}$ & $4.5 \mathrm{cdB}$ \\
\hline Positive control $^{\dagger}$ & $26.1 \mathrm{eA}$ & $26.1 \mathrm{eA}$ & $26.1 \mathrm{eA}$ \\
\hline
\end{tabular}

* Averages of three replicates. Different lower case letters within columns and upper case letters within rows show the differences between treatments (Tukey test, $P<0.05) .{ }^{\dagger}$ The positive control represent plants treated only with the pathogen M. oryzae.

\section{QUANTIFICATION OF ENZYMES RELATED TO RESISTANCE, SALICYLIC ACID AND PHENOLIC COMPOUNDS}

The results were analyzed by multivariate principal component analysis (PCA), which was performed based on data collected 24 and 48 hours before and after inoculation with M.oryzae. Among several graphs that were plotted, a greater explanation of the variables tested was observed when the results of each time were analyzed separately.Figures $2 \mathrm{~A}$ and $2 \mathrm{~B}$ are illustrating the biplot graphs derived from the multivariate principal component analysis (PCA), with the results of the enzymatic quantification, the concentration of salicylic acid and phenolic compounds, and the severity of leaf blast in rice plants after submission to treatments with standardized extract and fractions of R.graveolens.The graphs were plotted based on the best results, which were obtained with treatments at $6.75 \mathrm{mg} / \mathrm{mL}$, at 24 and 48 hours, before and after inoculation of the pathogen.

According to the PCA chart (Figure 2A), which is related to the results in the time of 24 hours before and after inoculation, it is observed that $65.39 \%$ of the total variance among the treatments under study were explained. The F1 axis accounted for the majority of the variability of the treatments (45.6\%), while the F2 axis accounts for $19.8 \%$ of these variations (Table 3 ).

In this way, it is possible to group the treatments according to the variables that most relate them. The F1 axis were loaded with the variables CHI, GLU, PAL and LOX $(P<0.05)$, which have a positive and significant correlation with the treatments of butanol (Fbut) and hydromethanolic (Fhidro) fractions, which are the one with the lowest concentrations of furanocoumarins tested (Table 3).

In view of this, these treatments may be acting as elicitors of the rice plants, once they have activated the aforementioned enzymes. On the other hand, the concentration of salicylic acid (AS) along with the suppression of leaf blast (SBF) had a negative correlation with these enzymes, which is explained by the fact that, for the formation of these enzymes, it is necessary to consume salicylic acid as precursor. In relation to SBF, the lowest SBF was confirmed in the treatments with butanol and hydromethanolic fractions, since this variable had a negative correlation with these treatments (Figure 2A).The POX did not present a positive correlation with the other enzymes, since this enzyme is nonspecific, presenting an increase in any stress situation. It was also observed that the highest correlation of the FBS was with the positive control (M.oryzae), which corresponds to the treatments inoculated only with the pathogen (Figure 2A).

According to the PCA graph (Figure 2B), which is related to the results in the time of 48 hours before and after inoculation, it is observed that $71.75 \%$ of the variations among the treatments were explained by the variables grouped in F1 axis (55.8\%), while the F2 axis accounted for $15.9 \%$ of these variations (Table3).There was a positive correlation between the treatments based on hydromethanolic fraction, extract and the butyl fraction with the enzymes CHI, GLU, LOX and POX, which indicates that, similarly to what was found at 24 hoursperiod, these treatments had a significant effect on differential expression/induction of these enzymes (Figure 3). The variation of PAL was strongly associated with treatments containing the hexane fraction after inoculation with the pathogen (Fhex + Py), and leaf blast suppression had an opposite correlation with this treatment. 
Analyzing Figure 3, we observedthe formation of clusters between the treatments. According to Figure $3 \mathrm{~A}$, which corresponds to the results of the 24-hour period, the treatments were split into 5 groups, where the ones encompassing the butyl and hydromethanic fraction were related both to leaf blast severity and enzymatic activity.

In the 48-hour period, the treatments were split into two groups. The treatments containing butyl, hydromethanolic and vegetal extracts (which had the lowest concentrations of furanocoumarins) without the presence of the pathogen remained in the same group; which demonstrates the relationship of these treatments with the results of the enzymatic activity and leaf blast severity evaluated in the study.
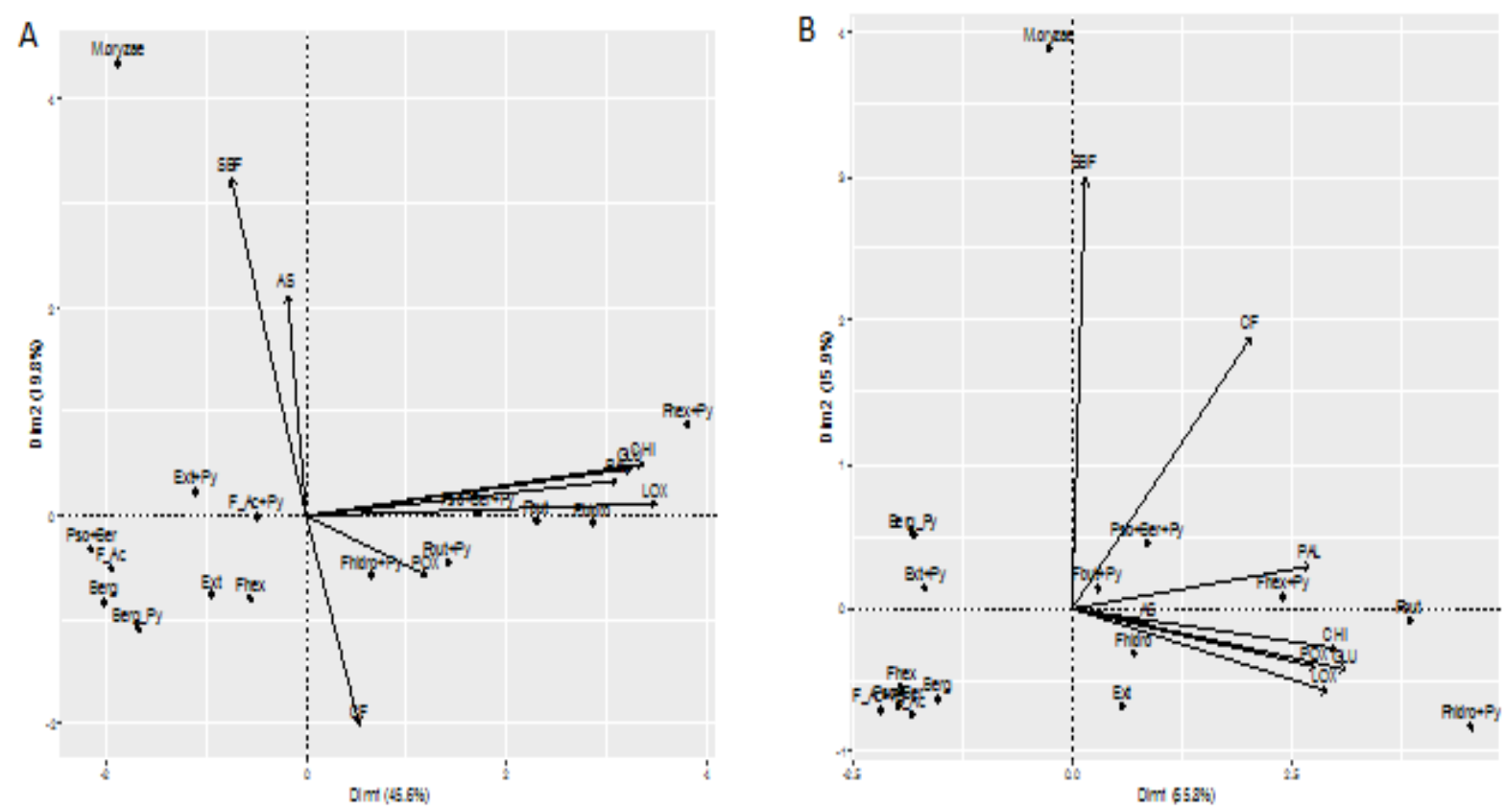

Figure2. Principal component analysis (PCA) of the results (A) at 24 hours before and after inoculation of the pathogen and $(B)$ at 48 hours before and after pathogen inoculation

A) 24 hours post-application

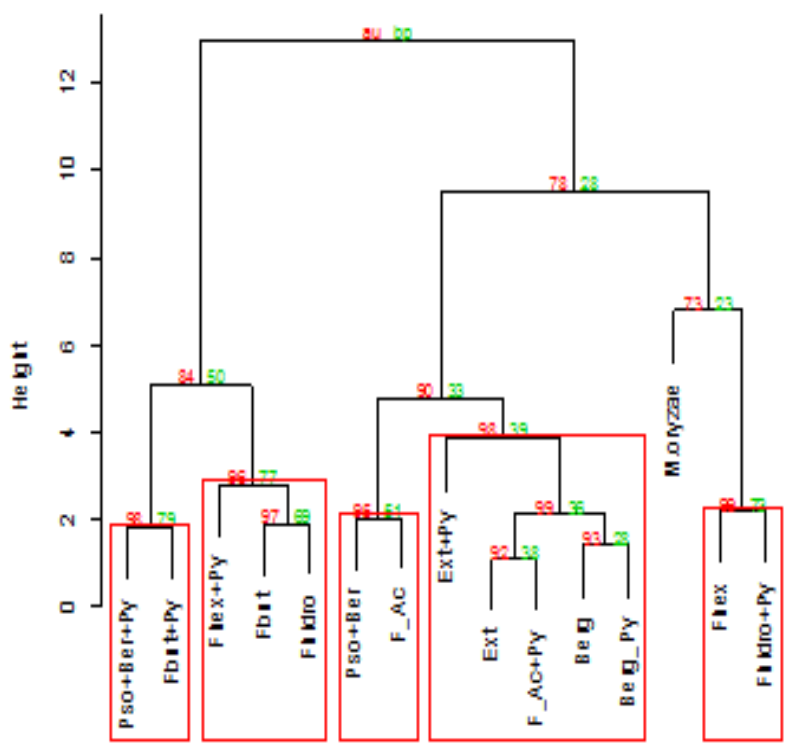

B) 48 hour 5 post-application

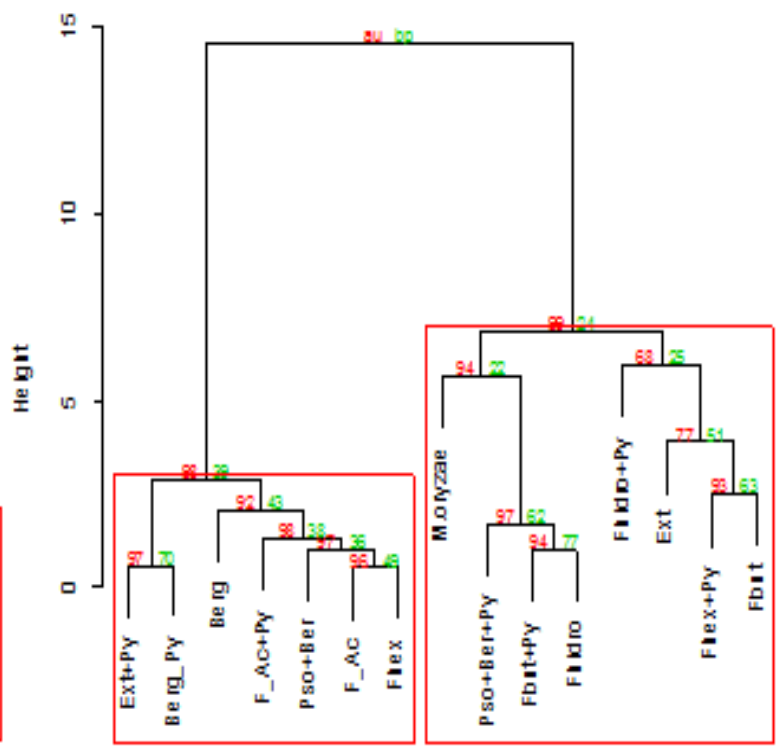

Figure3. Dendrogram of the result of cluster analysis by the Ward's hierarchical method using Euclidean distances based on eight variable responses, including enzymatic activities and blast severity. Significant similarities between treatments (red rectangles) are indicated with red values based on the approximate nonbiased $P$-value $>0.90$ (bootstrap resampling of 1000 replicates). 
Table3. Correlation matrix for enzymatic variables and blast severity related to treatments based on extract of $R$. graveolens and their respective fractions after application in rice plants inoculated with M. oryzae, and the dimensions of principal component analysis for 24 and 48 hours before and after inoculation (hai) of the fungus with significance of $P<0.05$.

\begin{tabular}{|c|c|c|c|c|c|}
\hline \multirow{2}{*}{ Variable responses } & \multicolumn{2}{|c|}{24 h.a.i. } & \multicolumn{2}{c|}{ 48 h.a.i. } \\
\cline { 2 - 5 } & Dim.1 & Dim.2 & & Dim.1 & Dim.2 \\
\hline Chitinase & 0.95 & $\mathrm{~ns}$ & & 0.93 & $\mathrm{~ns}$ \\
\hline$\beta$-1,3-glucanase & 0.91 & $\mathrm{~ns}$ & & 0.96 & $\mathrm{~ns}$ \\
\hline PAL & 0.87 & $\mathrm{~ns}$ & & 0.83 & $\mathrm{~ns}$ \\
\hline LOX & 0.98 & $\mathrm{~ns}$ & & 0.89 & $\mathrm{~ns}$ \\
\hline POX & $\mathrm{Ns}$ & $\mathrm{ns}$ & & 0.85 & $\mathrm{~ns}$ \\
\hline AS & $\mathrm{Ns}$ & 0.60 & & $\mathrm{~ns}$ & 0.58 \\
\hline CF & $\mathrm{Ns}$ & -0.57 & & 0.63 & 0.92 \\
\hline Severity (SBF) & $\mathrm{Ns}$ & 0.91 & & $\mathrm{~ns}$ & 1.27 \\
\hline Eigenvalues & 3.65 & 1.58 & & 4.47 & 15.90 \\
\hline Explainedvariance (\%) & 45.63 & 19.76 & & 55.85 & 71.75 \\
\hline Cumulativevariance (\%) & 45.63 & 65.39 & & 55.85 & \\
\hline
\end{tabular}

Dim. = Dimension derived from principal component analysis. $N s=$ not significant at $P<0.05$.

\section{DisCUSSION}

The plant extract of R.graveolens, as well as its fractions, has an inhibitory activity of the mycelial growth of M.oryzae, and these results can be verified in the work published by Arruda et al [29]. Faced with this first discovery, new studies were designed to define the compounds present in the extract and its fractions, which have suppressive activity against phytopathogens, as well as the mechanism of action by which these compounds act to provide the inhibition of M.oryzae. In this way the present work enabled the investigation and helped in the definition of the compounds with antifungal activity and in the determination of the concentrations of these that act directly against the phytopathogen and those that act in the induction of resistance process.

In this work, it was observed thatR.graveolens standardized extract in furanocoumarins has a striking suppressive activity against the fungal disease caused by $M$. oryzae, acting in the process of induction of resistance. This outcome supports the idea of being using this botanical extract in the integrated management of the rice blast, in order to mitigate the burden due to damages caused by this disease in rice crops.

The standardization of the vegetal extract in furanocoumarins, as well as its fractions[29], allowed us to determine the concentrations of these compounds with antimicrobial activity that elicit defense mechanisms of plants, as showed by this study with rice.It is important to mention that the process of fractioningused in the work directed us in the determination of the solvent with the capacity to extract more concentration of the furanocoumarins and to indirectly select the possible constituents that could beacting in synergism with the furanocoumarins.

Furanocoumarins as they were predominantly apolar compounds were easily extracted with the aid of a medium-polar solvent such as ethyl acetate [30]. On the other hand, the fraction of hexane, which has the characteristic of low polarity, has the propertyof extracting highly apolar compounds, such as waxes and fatty acids, and therefore is considered not a suitable solvent for the extraction of compounds such as furanocoumarins.

The higher concentration of furanocoumarins in the ethyl acetate fraction helped in the phytotoxicity process in the rice plants, causing the plant to obtain a higher energy expenditure and, hence, did not increase its resistance-related enzymes. Other elicitor compounds also depend on their concentration to benefit the target plant, as for example methyl jasmonate, which biological activity is dependent on the concentration used; in concentrations higher than $50 \mu \mathrm{M}$ this compounds can cause severe damages to plants,including senescence and even cell death. Conversely, at concentrations between 1 and $10 \mu \mathrm{M}$, methyl jasmonateactsinducing the expression of genes related to plant defences[31].

As apolar fractions caused phytotoxicity in plants before inoculation, the non-activation of plant defense mechanisms within 48 hours after induction may have been impaired, since the plants must have had a higher energy expenditure to try to recover from the phytotoxicity.However, after the inoculation with the pathogen, the activity of the enzymes was significantly increased in plants 
treated with furanocoumarins, when compared with the positive control (only plants inoculated with the pathogen).This resultcould be related to alonger period of recovery and activation defense mechanisms by plants, since after seven days when disease suppression was evaluated, the results were better than the control.

The analysis of results regarding the enzymatic quantification after submission to the treatments leads us to affirm that the butyl fraction, which presented the lowest concentration of furanocoumarins, allowed the elicitation of all enzymes related to rice resistance and considerably reduced the severity of leaf blast. However, it can be inferred that concentrations of $0.7 \mathrm{mgmL}^{-1}$ psoralen and $1.2 \mathrm{mgmL}^{-1}$ bergapten served as resistance inducers in rice plants. In this way the dose used of these compounds will direct to the result, with the caution for larger concentrations thatcan act on the pathogen but also cause toxicity to the host plant.

The use of plant extracts contributes to alleviatethe resistance of fungal pathogens to chemical fungicides with the great advantage ofminimizing the environmental impacts caused by the indiscriminate use of these synthetic substances.

The results obtained will be able to direct new studies related to the action mechanisms of plant extracts on phytopathogens. Particularly, our resultsrepresent a promising and innovative control tacticbased on the use of natural phytoalexinsproduced byrice plants induced with furanocoumarinderivatives of $R$. graveolans. Phytoalexins of rice belong to the group of terpenoid compounds, wherein themajor compounds known aremomilactone A and B, oryxalexins A-F and phytocassanes, and sakuranetina belonging to the class of flavonoids [32]. It is noteworthy that $R$. graveolens is easily domesticated and thus can be mass cultivated for production of furanocoumarins. The method os extraction of these furanocoumarins in the crude extract of $R$. graveolens is inexpensive and easily practiced. Therefore, costs related to $R$. graveolens cultivation and further extractions are relatively inexpensive which supports the feasibility of this alternative method of control toward M. oryzae.

In addition to the identification of phytoalexins, the ability of the standardized extract of $R$. graveolens in furanocoumarins to elicit other resistance mechanisms inrice plants should be analyzed, as well as examine the performance of this extract in relation to the beneficial microbiomeassociated with rice.

The plant extract of $R$. graveolens standardized in furanocoumarins acts as a natural elicitorof systemicresistance in rice plants, and can contribute to the reduction of leaf blast severity and may offer a biorational alternative to problems associated with the over-reliance of synthetic fungicides. The determining factor for induction of resistance mechanism in rice plants is directly linked with the concentration used of these compounds.

\section{REFERENCES}

[1] Mcdougall, P. The cost of new agrochemical product discovery, Development \& Registration and Research \& Development prediction for the future - A Consultancy Study A Consultancy Study for Crop Life America and the European Crop Protect for Crop Life America and the European Crop Protection Association on Association. Phillips McDougall, 2010.

[2] Conab, C. N. D. A. Perspectiva agropecuária. 2015. Disponível em: <http://www.conab.gov.br/ conteudos.php? $\mathrm{a}=1253 \&>$.

[3] Scheuermann, K. K.; Eberhardt, D. S. Avaliação de fungicidas para o controle da brusone de panícula na cultura do arroz irrigado. Rev. Ciên. Agrovet. v. 10, n. 1, p. 23-38, 2011.

[4] Resende, M. D; Nojosa, G.B.A; Cavalcanti, L.S; Aguilar, M.A.G; Silva, L.H.C.P; Perez, J.O; Andrade, G.C.G; Carvalho, G.A; Castro, R.M. Induction of resistance in cocoa against Crinipellis perniciosa and Verticillium dahliae by acibenzolar-S-methyl (ASM). Plant Pathol,v. 51, n. 5, p. 621-628, 2002.

[5] Gershenzon, J.; Dudareva, N. The function of terpene natural products in the natural world. Nat. Chem. Biol,v. 3, n. 7, p. 408-414, 2007.

[6] Paulino, R. C; Henriques, G.P.S.A; Moura, O.N.S; Coelho, M.F; Azevedo, R.A.B. Medicinal plants at the Sítio do Gois, Apodi, Rio Grande do Norte State, Brazil. Rev. Bras.Farmacogn. Rio Grande do Norte.v. 22, p. 29-39, 2012. 
[7] Amadioha, A. C.2000. Controlling rice blast in vitro and in vivo with extracts of Azadirachta indica. Crop Prot, v. 19, p. 287-290, 2000.

[8] Raj, S. N. Histo-chemical changes induced by PGPR during induction of resistance in pearl millet against downy mildew disease. Biol. Control. v. 60, p. 90-102, 2012.

[9] Wolters, B.; Eilert, U. Antimicrobial substances in callus cultures of Ruta graveolens. Planta Med.v. 43, n. 10, p. 166-174, 1981.

[10] Resende, M.L.V; Costa, J.C; Cavalcanti, F.R; Ribeiro Junior, P.M; Camilo, F.R. Seleção de extratos vegetais para a indução de resistencia e ativação de respostas de defesa em cacaueiro contra vassoura de bruxa . Fitopatol.bras., Brasilia.v.32.3, p213-221, 2007.

[11] __ Farmacopeia Brasileira. ANVIS A. Brasília-DF: 546 p. 2010.

[12] Martins,F.S; Moraes, C.S; Bara, M.T.F; Conceição, E.C. Obtainment and characterization of raw material of Brosimum gaudichaudii Trecul (Moraceae). J. Pharm. Res. v. 4, p. 3, 2010.

[13] Guideline, I. H. T. Stability Testing: Photostability Testing of New Drug Substances and Products. Q1B, Current Step.v. 4, 1996.

[14] Araújo-júnior, C. A. D; Costa, F.S; Taveira, S.F; Marreto, R.N; Valadares, M.C; Lima,E.M. Preparation of pellets containing Pothomorphe umbellata extracts by extrusion-spheronization: improvement of 4-nerolidylcatechol photostability. Rev. Bras.Farmacogn.v. 23, n. 1, p. 169-174, 2013.

[15] Prabhu, A. S.; De Filippi, M. C. C. Brusone em arroz: controle genético, progresso e perspectivas. Embrapa Arroz e Feijão Santa Antonio de Goiás, GO, 2006.

[16] Filippi, M. C.; Prabhu, A. S. Phenotypic virulence analysis of Pyricularia grisea isolates from Brazilian upland rice cultivars. Pesq. Agropec.Bras.,v. 36, n. 1, p. 27-35, 2001.

[17] Filippi, M. C; Cortes, C; Beckerman,J; Sweigard, J; Valent, B; Gonzalez,C; Ebbole, D. Novos aspectos da patogenicidade de Magnaporthe grisea. Santo Antônio de Goiás-GO. Embrapa Arroz e Feijão, 2006.

[18] Notteghem, J. Cooperative experiment on horizontal resistance to rice blast. INTERNATIONAL RICE RESEARCH INSTITUTE (Los Baños, Filipinas). Blast and upland rice: report and recommendations from the meeting for international collaboration in upland rice improvement. Los Baños. p.43-51, 1981.

[19] Bradford, M. M. A rapid and sensitive method for the quantitation of microgram quantities of protein utilizing the principle of protein-dye binding. Anal. Biochem.v. 72, n. 1, p. 248-254, 1976.

[20] Kuc, J. Association of b-1, 3 glucanase activity and isoform pattern with systemic resistance to blue mold in tobacco induced by stem injection with Peronospora tabacina or leaf inoculation with tobacco mosaic virus. J. Physiol Mol. Plant Pathol., v. 39, p. 2500-2530, 1991.

[21] Côrtes, M.V.C.B; Viana, H.F; Silva, F.R; Lobo, V.L.S; Silva, G.B; Prabhu, A.S; Filippi,M.C.C. Quantificação da atividade enzimática de proteínas relacionadas à patogênese no patossistema Oryza sativa/Magnaporthe grisea. Santo Antônio de Goiás-GO, 2008.

[22] Axelrod, B.; Cheesbrough, T. M.; Laakso, S. Lipoxygenase from soybeans: EC 1.13. 11.12 Linoleate: oxygen oxidoreductase. Meth. in Enzymol.,v. 71, p. 441-451, 1981.

[23] Alunni,S ;Cipiciani, A; Fioroni, G; Ottavi, L.Mechanisms of inhibition of phenylalanine ammonia-lyase by phenol inhibitors and phenol/glycine synergistic inhibitors. Arch. Biochem. Biophys.v. 412, n. 2, p. 170-175, 2003.

[24] Saikia, R; Kumar, R; Arora, D.K; Gogoi, D.K; Azad, P. Pseudomonas aeruginosa inducing rice resistance againstRhizoctonia solani: Production of salicylic acid and peroxidases. Folia Microbiol.v. 51, n. 5, p. 375-380, 2006.

[25] Yalpani, N; Léon, J; Lawton, M.A; Raskin, I. Pathway of salicylic acid biosynthesis in healthy and virus-inoculated tobacco. Plant physiol.v. 103, n. 2, p. 315-321, 1993.

[26] Van Der Rest, B.;Danoun, S; Boudet, A.M; Rochange, S.F. Down-regulation of cinnamoyl-CoA reductase in tomato (Solanum lycopersicum L.) induces dramatic changes in soluble phenolic pools. J. Exp. Bot.v. 57, n. 6, p. 1399-1411, 2006. 
[27] Husson, F; Josse, J; Le, S; Mazet, J. FactoMineR: Multivariate Exploratory Data Analysis and Data Mining. R package version 1.31.4, 2015. http://CRAN.R-project.org/ package $=$ Facto MineR.

[28] Suzuki, R; Shimodaira, H. pvclust: Hierarchical Clustering with P-Values via Multiscale Bootstrap Resampling. $\mathrm{R}$ package version 2.0-0., 2015 http://CRAN.R-project.org/package= pvclust

[29] Arruda, R.L; Garcia, M.L; Côrtes, M.V.C.B; Filippi, M.C.C; Conceição, E.C. Use of Ruta graveolens L. Vegetable Extract Standardised by furanocoumarin content to control Magnaporthe oryzae in Rice plants. Int. J. Res. Stud. Biosci. v.3 (9), p.94-103, 2015.

[30] Larbat, R. Kellner, S; Specker, S; Hehn, A; Gontier, E; Hans, J; Bourgaud, F; Matern, U. Molecular Cloning and Functional Characterization of Psoralen Synthase, the First Committed Monooxygenase of Furanocoumarin Biosynthesis. J. Biol. Chem.v. 282, n. 1, p. 542-554, 2007.

[31] Mason, H. S.; Mullet, J. E. Expression of two soybean vegetative storage protein genes during development and in response to water deficit, wounding, and jasmonic acid. The Plant Cell.v. 2, n. 6, p. 569-579, 1990.

[32] Arruda, R.L; Paz, A.T.S; Bara, M.T.F; Côrtes, M.V.C.B; Filippi, M.C.C; Conceição, E.C. An approach on phytoalexins: function, characterization and biosynthesis in plants of the family Poaceae.Ciênc. Rural, Santa Maria, v.46, n.7, p.1206-1216, 2016.

Citation: R. Arruda, et al., "Plant Extract of Ruta Graveolens Standardized in Furanocoumarins: Resistance Elicitorin Rice Plants against Magnaporthe Oryzae", International Journal of Research Studies in Biosciences (IJRSB), vol. 5, no. 8, p. 21, 2017, http://dx.doi.org/10.20431/2349-0365.0508003.

Copyright: (C) 2017 Authors. This is an open-access article distributed under the terms of the Creative Commons Attribution License, which permits unrestricted use, distribution, and reproduction in any medium, provided the original author and source are credited. 